\title{
The Effects of Participation
}

\section{Women in Post Conflict Ayacucho, Peru}

\author{
By Sandra Portocarrero
}

\section{Abstract}

几

This paper examines the effects of participation and the importance of organizational ties in the lives of Andean women in Ayacucho, Peru. For over two decades (1980-2000), the country of Peru went through an internal conflict that entailed serious crimes mostly committed by the Shining Path and the Peruvian Army. Ayacucho was the most affected region during the conflict, leaving poverty and dramatic consequences throughout the area. Today, the economic development of Ayacucho is slow yet a number of grass roots organizations have allowed different segments of the population to improve their quality of life. This paper focuses on the women members of the National Association of the Relatives and Disappeared of Peru (ANFASEP), paying special attention to the importance of the organizational ties that have emerged within the organization and the reproduction of social capital. Using the data collected through forty-eight in-depth interviews, I claim that the more women participate in the organization, the better their quality of life and economic well-being is. My findings suggest that organizations have allowed them to access resources that affect their quality of life in a positive manner as long as the members remain active. This paper makes an important contribution to the literature on women's movements in Latin America, using Peru as a case study, offering key insights about the evolution of women's movements into institutionalized organizations. 
When Isabel wakes up in the morning, she takes a shower with cold running water and gets ready to start her day. She places the coffee, chaplas ${ }^{1}$, milk, butter, and sugar on the table. She asks her two sons to join her and has breakfast with them. Isabel has a different plan every day: one day she will go and sell cheese in the market, another day she will go back to the fields and pick up some cereals to sell in the city of Huamanga. Others, she will simply stay home and make a variety of crafts to sell to the European and American tourists who wander the streets of the Andean province of Ayacucho, Peru.

Every afternoon she meets with the women in her community to plan how they are going to improve their neighborhoods. Isabel and her female neighbors go out of their way to organize everyone on the block and to encourage them to participate in different activities. Their current interest is to pave the streets of their neighborhood with asphalt. Isabel knows that her life has different purposes and she is happy that way. Her life, however, has not always been this way. Two decades ago, Isabel's husband went to play soccer with his friends before dinner. He forgot to take his Peruvian identification card. Isabel's husband was a simple guy: he worked fixing doors, and had managed to generate a small income to support his family. After he left, Isabel waited for him with dinner ready on the table. Isabel's husband never came back.

The story of her past is not unique. Thousands of women lost their husbands and sons during the internal conflict in Peru. Carmela also lost her husband in a similar manner. Both Carmela and Isabel were in their early twenties when the violence in Ayacucho escalated. They both migrated to Huamanga during the eighties and had a similar amount of money saved when they became widows. They both had two children when they arrived in the city. Though they both share a similar story, their current lives are very different. Carmela wakes up in the morning and washes herself with some rainwater she has managed to collect throughout the week. She serves chaplas, butter, and tea for breakfast, which she shares with her two children as well. She does not have a kitchen, for she cannot afford to buy propane gas to cook. After breakfast, Carmela will work around the house, go out and look for pieces of wood so she can prepare lunch and dinner. She will also knock on some doors and see if someone needs help with their laundry. Carmela charges a dollar per day worked. After she is done with her duties, Carmela will take a nap and wake up around two in the morning to go out to the local bars and pick up empty bottles. If she is lucky, she will manage to collect about thirty bottles and sell all of them for about fifty cents before dawn.

\section{Introduction}

Carmela and Isabel live three blocks away from each other. Their stories are surprisingly similar. Yet their current life conditions are significantly different. Both Carmela and Isabel are members of the National Association of Relatives of the Kidnapped and Disappeared of Peru (ANFASEP). The majority of ANFASEP members are women. They founded the association in 1983, out of a need to organize and protect themselves from the ongoing violence during the internal conflict in Peru.

Carmela and Isabel are two of the forty-eight women I interviewed for this project. I was surprised by how similar their backgrounds are. However, while Isabel is highly involved in ANFASEP, Carmela only attends mandatory meetings. For both Carmela and Isabel, being a member of ANFASEP is an important part of their identity: it is what reminds them that justice for them and their relatives has not yet been attained. Although being connected to ANFASEP is important for both of them, Isabel benefits from the resources that result from the networks embedded in the organization more than Carmela. 
In this paper, I explore the effects of participation in ANFASEP in the lives of its female members; I specifically focus on how the level of participation in ANFASEP affects the economic and personal well-being of its members. I argue that the institutionalized relationships between the ANFASEP members have become strong social networks that produce an aggregate of resources also known as social capital. Thus, the women who are more involved in ANFASEP benefit more from the resources that are offered by and through the organization.

The region of Ayacucho, considered an indigenous space in the ethnogeography of Peru (Orlove 1993), was the most heavily affected by the internal conflict, with 40 percent of warera deaths and disappearances taking place in the region (CVR 2003, 4-10). In recent years, a number of anthropologists and historians have produced a growing body of literature that focuses on the reconstruction of the story of the internal conflict. ${ }^{2}$ Yet little work has been produced to understand the consequences and the dynamics between people, networks, communities, institutions, and organizations in the most affected regions.

Most contemporary work focuses on the relationship between the history of violence and memory in Peru, ${ }^{3}$ and on the politics of memorializing the country's internal armed conflict. ${ }^{4}$ My interview-based study contributes to the empirical literature on the conflict. I offer a contemporary analysis of the benefits of participation in a key organization that emerged during the times of war in the current lives of the women who were among the most affected during the conflict.

My data supports the theoretical claim that high levels of participation in an organization allow women to access the resources or social capital that is generated by active organizational networks. Furthermore, by analyzing a segment of the women of Ayacucho, my study deconstructs the homogenous image of "Andean women affected by the conflict" found in the current literature and challenges the few contemporary explanations of the current dynamics of the region, which tend to propose "one size fits all" solutions to improve the quality of life for these women.

The next section of this paper provides a historical narrative of the internal conflict in Peru, giving a general overview of the situation in Ayacucho during the years between 1980 and 2000. Following this historical narrative, I offer a review of the literature on women's movements, gender interests, and social capital. After the literature review, I combine historical data with the responses of my interviewees to offer a fair description of the emergence of ANFASEP. With the intention of offering a story that allows the reader to understand the consequences of the conflict, I present my empirical findings in chronological order: I first talk about the consequences of violence in the population, followed by the emergence of women leaders in the region, and ultimately discuss the emergence of civil society organization throughout the region and its effects on the economic and personal well-being of its female members, using ANFASEP as a case study. My methods section can be found as an appendix to this paper. I chose in-depth interviews as my primary methodology, and used participant observation as a secondary research method. I conclude my paper reflecting on the social significance of my research, limitations, and additional questions that emerged from this research.

$2 \quad$ Lehrer et al. 2011; Logan and Reeves 2009; White 1997; Williams 2007.

3 Bracamonte et al. 2003; Degregori 2003; del Pino 2003; González 2011; Jiménez 2009; Milton 2007; Theidon 2004; Vich 2002.

$4 \quad$ Cánepa 2009; Drinot 2009; Hite 2007; Milton 2011; Milton and Ulfe 2011; Poole and Rojas-Pérez 2011; Rodrigo 2010; Ulfe 2009. 


\section{The Internal Conflict in Peru}

Peru's Internal Armed Conflict took place between the years of 1980 and 2000. It is considered the longest and most destructive conflict Peru has experienced. The fundamental cause of the internal conflict in Peru was the decision of the Shining Path to declare an armed struggle against the Peruvian State.

In the early 1980s, the Shining Path had organized as a Maoist political group led by Abimael Guzman, a philosophy professor at the San Cristobal of Huamanga University in the province of Ayacucho, Peru. Using systematic methods of extreme violence and terror, without respect for basic norms of war and human rights, the Shining Path initiated armed violence against the civilian population. Such subversive violence was directed towards the people who represented the "old order" and who had no interest in joining the armed struggle. Thus, the victims of the Shining Path were mostly Andean peasants or community organizers and not members of the political or economic elite of the country.

In order to face the threats of the Shining Path, the Peruvian State had the duty to respond to the violent acts and protect the Peruvian population. When the Peruvian State intervened, the number of fatal casualties increased; human rights violations escalated as the government reacted against the insurgency.

Using a statistical technique called Multiple Systems Estimation, The Peruvian Commission of Truth and Reconciliation (CVR) has estimated that the number of fatal victims during the conflict might be 69,280 people (CVR, 2003:2-9). Using this same technique, the CVR has also estimated that about 26,259 persons died or disappeared in the province of Ayacucho between the years of 1980 and 2000.

According to the Commission of Truth and Reconciliation, the Peruvian State Auto Defense Committees and paramilitary were responsible for about $37.26 \%$ of the deaths and disappearances. ${ }^{5}$ In their final report, the CVR states:

At times and in certain places, the Armed Forces had a generalized and systematic practice of violation of human rights and [...] there is evidence to claim that they violated international human rights (CVR 2003: 1,33).

The fact that such a large number of people died at the hands of the Peruvian Army suggests that the Peruvian State violated their fundamental duty of protecting the Peruvian citizens.

\section{Molyneux and Bourdieu: Understanding Women's Movements and Social Capital}

The sociological literature on Third World women's movements is not vast. The approach used to describe and analyze Third World women's organizing techniques tend to homogenize women's interests and political stands. Oftentimes the women are portrayed as passive victims. In fact, much of the literature on the women of Ayacucho portrays them as violated (Boesten, 2010), victims (Theidon, 2004), uneducated, indigenous, and poor (Degregori, 2003).

The case of ANFASEP shows the capacity of women to organize in a post-conflict society in one of the poorest regions in Peru and their capacity to survive and create resources for others. In order to understand the capacity of women to organize for social change, it is 
necessary to recognize the different interests among women. Maxine Molyneux (2001), in "Women's Movements in International Perspective: Latin America and Beyond," states that a false homogeneity has been imposed to the notion of women's interests. To create a framework for differentiation, she proposes to call the general interests that women may have in common gender interests.

Gender interests are those that women may develop by virtue of their social positioning through their gender attributes. These may be either strategic or practical. Strategic gender interests are derived from an analysis of women's subordination and from the formulation of a more satisfactory set of arrangements than the existing one. Molyneux believes that strategic gender interests are the ones most frequently identified by feminists to be women's real interests. On the other hand, practical gender interests arise from the concrete conditions of women's positioning within the gendered division of labor. They are "a response to specific and immediate needs, and therefore do not always challenge the current forms of gender subordination" (2001:43).

Molyneux argues gender and class are loosely intertwined and that practical interests cannot be assumed to be innocent of class effects. As an example, Molyneux says that women who are primarily responsible for their household's daily welfare will withdraw their support from governments that fail to provide the basic needs for their households. Thus, it is no surprise that, compared to other classes within our society, poor women tend to be willing to mobilize and organize because of economic necessity.

Molyneux's attempt to conceptualize gender interests to explain women's consciousness suggests that the ways these interests are considered vary across space and time and are shaped by the circumstances surrounding women. Although she focuses on the political circumstances and the role of the state, her conceptualization of gender interests can be applied to understand various examples of the emergence and evolution of women's movements throughout the world. Two key points she offers when analyzing the formulation of gender interests are 1) it is important to consider the circumstances, for this will allow us to consider the possibilities as well as the limits of cross-cultural solidarity, and 2) women's unity on gender issues cannot be considered as a given, for unity is constructed (Molyneux, 2001:45)

The case of ANFASEP is an interesting one, for it suggests that practical and strategic interests are not mutually exclusive. Rather, they can complement each other: strategic gender interests can influence the emergence of practical women's interests and vice versa. For example, women members of ANFASEP are not happy with the current set of political arrangements surrounding them, and in order to challenge them, the women define their strategic gender interests and organize. They have a bigger goal, but while they are working for their goal, they face challenges that require specific and immediate solutions. The women define their practical gender interests to face these immediate needs, without forgetting about their strategic gender interests, and continue to work on their bigger goal of challenging the current political arrangements.

Ray and Korteweg (1999) argue that most of the literature written about women's movements in Latin America looks at mobilization based on motherhood. They state:

According to the literature, women's mobilization around human rights issues in bureaucratic authoritarian regimes was explicitly grounded in their identities as mothers. Schirmer (1989), Femenía (1987), and Noonan (1995) discuss groups such as the Madres de la Plaza de Mayo in Argentina, the Mutual Support Group (GAM) in Guatemala, and the Group of Relatives of the Detained- 
Disappeared (Agrupacíon) in Chile, which mobilized around the issue of forced disappearances. These authors argue that while the state valorized traditional notions of motherhood and family, women inverted this image by using their motherhood status to agitate for the return of the disappeared (dead or alive), and the punishment of their torturers and murderers (Ray and Korteweg, 1999).

The Peruvian case is similar, for it was while they looked for the bodies of husbands and sons that the women of ANFASEP met, and it was their status as wives and mothers that triggered mobilization in Ayacucho.

There is an extensive body of literature focusing on the emergence of women's movements from historical and cross-cultural perspectives. Common interests lead to organizing which leads to the development of social networks. The solidification of these social networks can influence the economic outcomes of the people participating in the network through the generation of what many scholars have called social capital.

Though the term is widely used in modern sociology, the literature on social capital suggests that there is no real consensus on what it actually means and it is therefore a concept in progress. The idea of social capital is not a new one: Marx's distinction between an atomized class-in-itself and an effective class-for-itself, or Durkheim's emphasis on group life as an antidote to anomie and self-destruction, clearly suggest that positive outcomes for both the individual and community can emerge from group participation and social networks (Portes, 1998). Social scientists like Hanifan (1916), Jacobs (1961), Loury (1977), Coleman (1988), and Becker (1994) have brought the concept of social capital into different fields, such as economics, public policy, and sociology.

Pierre Bourdieu conducted the first systematic analysis of social capital, defining it as "the aggregate of the actual or potential resources that are linked to the possession of a durable network of more or less institutionalized relationships of mutual acquaintance or recognition" (Portes, 1998). According to Bourdieu (2001: 96-7), capital is a vis insita, a force inscribed in objective or subjective structures, but it is also a lex insita, the principle underlying the regularities of the social world. Bourdieu does not refer to social capital as the equivalent of social networks nor as the equivalent of the relationships an individual possesses. Instead, he describes social capital as the resources an individual can access through social networks and maintain through them. Therefore, the social network becomes an access route to social capital.

Furthermore, Bourdieu states that these networks must have a highly distinguishable characteristic: they are long lasting networks, based on institutionalized relationships in which there is acceptance and mutual recognition. These networks are the product of efforts of association that individuals start to create access to material or symbolic benefits. Sociologists like Mark Granovetter (2005) have paid particular attention to the relationship between social networks and economic resources in different contexts and have analyzed social networks as social structures that affect the economic outcomes of the individuals in the network.

Others have demonstrated through their empirical findings that organizing can lead to the generation of social capital and have a positive impact in diverse organizational networks of support (Enriquez, 2000). An instance in which the generation of social capital through organizing had a positive impact for rural organizations is the case of the small farmers in San Dionisio, Nicaragua presented by Laura Enriquez. In this context, organization was these farmers' salvation (Ibid, 2000: 47-68). Organizations provided them with at least some of the resources that had been cut off as a result the political changes that emerged with the initiation of the Chamorro government in 1990. Enriquez argues, "farmers who were organized were much 
more likely than the unorganized to receive the benefits that might come from the relationships with international organizations for the simple reason that, from the point of view of the funders, their organizations facilitated the implementation of projects" (Enriquez, 2000). According to Enriquez, the organizational networks of support of the kind found in the case of San Dionisio resembled what some have spoken of as "social capital."

The attention given to this concept has also been influenced by powerful entities such as the World Bank, which has created a particular conception of social capital, baptizing it as "the missing link in the effort to end poverty in the developing world" (Grootaert 1977). ${ }^{6}$ According to the World Bank, social capital refers to the norms and networks that enable collective action. It encompasses institutions, relationships, and customs that shape the quality and quantity of a society's social interactions. Social capital is a critical element for societies to prosper economically and for development to be sustainable. When enhanced in a positive manner, social capital can improve project effectiveness and sustainability by building the community's capacity to work together to address their common needs, fostering greater inclusion and cohesion, and increasing transparency and accountability.

One of the scholars whose research is financed by the Social Capital Initiative, Anthony Bebbington (2000), argues that social capital has played an important role in determining the success of Andean communities to achieve economic and social sustainability. Bebbington defines social capital as horizontal forms of association and networks that cut across and link associations, markets, and state actors. Social capital forms the basis of a fortified civil society, which in turn encourages state responsiveness and market efficiency and inclusiveness (Enriquez, 2010:25). For Bebbington, social capital was instrumental in helping citizens negotiate more effective and productive relationships with both the state and the market.?

\section{The Formation of ANFASEP}

We went to look for people's bodies, and I found my husband's body. Picked it up, my kid was on my back. At noon, I got to the public prosecutor's office, and I told the public prosecutor "Sir, here is my husband." Many people were looking and the moment I found him, I became even more stubborn, I wanted to keep looking... many documents were accepted at that moment. Everyone told me to quit, but the mayor encouraged me to continue, we women never gave up...but the mayor was also killed in $1991 .^{8}$

The militarization of the conflict occurred when the Peruvian Military Command entered the scenario of violence. After the installation of the Peruvian Military Command in Ayacucho in the beginning of the 1980s, the victims multiplied. Their family members, mostly women, would walk around the streets of Ayacucho and the Plaza Mayor, would stand in the doors of the court

6 The World Bank, through its Social Capital Initiative, has financed the research of authors in different parts of the world such as Bebbington and Carroll (Induced Social Capital and Federations of the Rural Poor in the Andes), Gugerty and Kremer (Building Social Capital through Assistance to Women's Groups and Primary Schools in Kenya), Colleta and Cullen (Social Capital and Violent Conflict: Case Studies from Cambodia and Rwanda).

$7 \quad$ The body of literature produced by the scholars funded by the Social Capital Initiative suggests that social scientists need to put an emphasis on norms and networks that can produce collective action within civil society in order to end poverty. The problem with this focus is that no matter how strong or wide a social network is, the end of poverty cannot rely primarily on civil society institutions. Focusing merely on the positive effects of social capital deviates our attention from the structural problems of a capitalist economic system. 
houses, police stations, and churches. Small groups of women formed and would exchange information about their cases as well as try to cope with their pain together.

As the violence increased, lawyers, judges, public prosecutors, and various agents related to the administration of justice in Ayacucho stopped fulfilling their roles because they were afraid of being assassinated by Shining Path members. The Peruvian state gave the Armed Forces total control of the Central Andes: every action in society required the approval of the Peruvian Military Command. This situation stopped the relatives of the disappeared from starting or following up their legal appeals. On a visit from the Latin American Federation of the Association of Relatives of Disappeared and Detained (FEDEFAM), the situation of the relatives was registered:

A cadaver can only be inspected by a Judge or a Public Prosecutor, who has to obtain both the consent and the means of transportation from the Political-Military Command. The consent is rarely granted, therefore the cadavers stayed untouched wherever they were found for weeks until they are devoured by animals (FEDEFAM 1984:30).

If the relatives removed the cadavers without any public authority present, then they would lose the right to denounce the atrocities. Within this context, only a few public figures whose authority was repressed by the Peruvian Military Command supported the emergence of ANFASEP. One of them was Leonor Zamora, who served as mayor of Huamanga from 1983 to 1986. Zamora played a fundamental role in the emergence of ANFASEP: she opened her house and office so that the members could get together there and organize. She convinced the Provincial Municipality of Huamanga to create a space where the relatives could share their stories and managed to convince beneficent institutions to donate food for the relatives. A meeting held on September 2, 1983, can be considered ANFASEP's first official meeting.

A few days afterwards, three female members of the organization traveled to Lima with the idea of presenting the reports of their disappeared relatives to the Central Government. They spent the night at the Campo de Marte, a park and recreation space in Lima. There, they met Zósimo Roca, a young lawyer who also happened to be from Ayacucho. Roca became their legal advisor. He typed the documents and represented them legally. After the first meeting, the goals of the organization were hard to set. Many of my respondents remember the role of Roca in the formation of the organization. One of them shared the following recollections:

A: "So, how did you join the organization?"

B: "In 1983 I met a group of women who looked for the bodies of their husbands together...It was not called ANFASEP yet...I would go to the lawyer Roca to seek for legal help. The lawyer suggested that we form an organization... we started organizing and collected funds to go to Lima for a protest..."9

Prior to adopting the name ANFASEP, the members named the organization the "Committee of Disappeared Relatives" (CFD), and chose Angelica Mendoza de Ascarza, also known as Mama Angelica, as their leader. A natural leader, Mama Angelica became the iconic figure of ANFASEP. When asked how they joined the organization, 65 percent (thirty-one 
out of forty-eight of the interviewees mentioned that Mama Angelica had encouraged them to do so). ${ }^{10}$

A crucial point in the consolidation of the organization was when FEDEFAM sponsored three ANFASEP members, including Mama Angelica, Guadalupe Ccallocunto, and Zósimo Roca, to participate in the Fifth FEDEFAM Congress in 1984, which took place in Buenos Aires, Argentina. When the ANFASEP members connected with other organizations and experienced international solidarity, the effort and desire to formally organize increased. In December 1984, the name was officially changed to ANFASEP. It was called a National Association because groups of relatives in two other provinces, Huancavelica and Apurimac, decided to join them (those two chapters no longer exist).

ANFASEP formed a junta directiva, or executive board, that managed to negotiate a space where the ANFASEP members could meet with the Education Workers of Huamanga Labor Union. Indeed, many educators disappeared during the conflict and their relatives became members of ANFASEP, so the request was quickly granted by the Labor Union.

A number of significant events occurred in 1985. For example, on January 19 and 20, the first National Meeting of Human Rights was held. The National Human Rights Commission ${ }^{11}$ (CNDDHH) was formed during the meeting. At that time, the principal allies of ANFASEP were the former National Commission of Human Rights (CONADEH) ${ }^{12}$ (now Commission of Human Rights ${ }^{13}$ ), the Service of Peace and Justice (SERPAJ) ${ }^{14}$, and the Association Pro-Human Rights (APRODEH) ${ }^{15}$, among others. When the pope visited Ayacucho in 1985, ANFASEP was inspired to seek support from local churches. However, because of the strong church-state relationship, including religious leaders such as bishop Ritcher and his successor Juan Luis Cipriani, they did not obtain any support from the church. As the influence of the organization within the population increased, so did the state's repressive tactics. In 1988, Zósimo Roca was persecuted by the Armed Forces and managed to escape to Lima. In 1990, fifteen members of the armed forces broke into Guadalupe Ccallocunto's house. Guadalupe had traveled with Roca and Mama Angelica to Buenos Aires, Argentina. When she went back to Ayacucho, Guadalupe disappeared. In 1991, Leonor Zamora, the mayor of Huamanga who had helped the women organize, also disappeared.

\section{Taking a Step Back:Violence During the Conflict}

After recounting the story of the conflict, I became aware of the need to understand what Slavoj Zizek would call the subjective violence ${ }^{16}$, that is, the violence perpetrated by an identifiable agent, that took place during the conflict and its consequences at both the individual and community levels. When describing their past, none of my respondents use the word "violence," but they offer

\footnotetext{
10 Because her skills and leadership were not representative of the rest of the members, Mama Angelica's interview was not included in this study yet it was considered when developing the story of ANFASEP in this paper.

11 Cordinadora Nacional de Derechos Humanos (CNDDHH).

12 Cordinadora Nacional de Derechos Humanos (CONADEH).

13 Comisión de Derechos Humanos

14 Servicio de Paz y Justicia

15 Asociación Pro-Derechos Humanos

16 Although Zizek would claim that what is required to understand the logic behind acts of subjective violence is to step back from the visible violence and understand the forms of objective or systemic violence, I limit myself to refer to subjective violence for my respondents did not offer any sort of analysis of the objective violence during the conflict.
} 
a vivid description of the types of violent acts they experienced and witnessed and have a clear understanding of their experiences during the conflict.

For example, an interviewee from Huamanguilla portrays with her testimony different types of violence she went through: the assassination of her husband, dispossession of her means of production, and sexual abuse:

My husband and I lived in Huamanguilla, we were dedicated to commerce... They (the Army soldiers) invaded our house and our store. They took our groceries and money...then they came into my store six months after my husband disappeared: You are a terrorist! - One said. One of them started to touch me, another one was touching my niece. ${ }^{17}$

Not all respondents experienced these types of violence, but the content of her story provides a reference to understand the situation of the women of Ayacucho during these two decades. My interviewees' responses suggest that there were three prominent types of consequences of the violence during the conflict.

\section{i. Dispossession of Their Means of Production}

Although using a binary logic tends to homogenize populations, it is helpful in this case to compare and contrast the rural and the urban populations in order to understand the different outcomes of these groups. A tactic both the Shining Path and the Peruvian Army used to exercise power over the peasants in rural Ayacucho was to take over their homes, land, and animals, forcing the population to migrate to cities like Huamanga or to hide in the mountains. Maria, a rural woman, offers a description of her experience with the violence:

The soldiers kicked out our family and took our house. They (the soldiers) settled in Trigopampa. They settled there... I went to the fort and I asked for help...in Cangallo... Acopro... ampamarca...there were so many bodies in those areas... there were days we would hide...for days...twelve days! Every month we would pick up maize, we took care of our land...but the military came in and took our maize... they took the best crops, many times...and left the worse for us... ${ }^{18}$

When the different armies took over their homes, they were either burned down, or occupied. By dispossessing peasants from their means of production, the population's fear of the Shining Path and the Peruvian Army increased. Celeste, a peasant woman who worked on a hacienda, explains the events that left her with no home, no job, and no belongings:

I had no animals... with only one change of clothes, they burned all my belongings... The hacienda I worked for, they burned it down, so many cows... beans, the house was full! It was a big facility...they poured the gasoline, and burned it down...our house... and the hacienda... was left to ashes, it was so big. ${ }^{19}$

The fear of the population towards the Shining Path and the Peruvian Army was one of the psychological consequences of the conflict. In this way, it was easier for both armed groups

$17 \quad$ Interview, June 23, 2011

18 Interview. July 1, 2011

19 Interview, July 1, 2011 
to exercise power over the civilians. But this tactic also led to increased poverty throughout the region. Ayacucho was already a poor region prior to the conflict, and the atrocities that took place during the 1980s and 1990s aggravated the situation of the region. Currently, Ayacucho is the sixth poorest region of Peru, ${ }^{20}$ and its poor economic situation can be attributed, though not exclusively, to the dispossession of the means of production of the population throughout the conflict.

\section{ii. The Creation of a New Status: Terrorists}

Many civilians and Peruvian Army soldiers used the term "terrorist" to refer to those who could potentially join the Shining Path. If one was a peasant, an indigenous person, or came from an Andean community, soldiers simply assumed that they would join the armed struggle and considered that person a terrorist. This simple logic caused the death of thousands of peasants and Andean dwellers.

The mass marginalization of indigenous people in Ayacucho made the life chances of all of those who were thus considered "terrorists" fairly similar. It is important to point out that the ones who stayed in Ayacucho were the poorest people in the region and the ones affected the most. Those who had more resources left Ayacucho in search of security. The citizens who were affected the most shared common life chances during and after the conflict and, as I will explain later on, now share similar interests.

Marcela, a respondent, argues that her husband was considered a terrorist because he served the community. The Peruvian Army soldiers "disappeared" her husband:

My husband knew how to use the typewriter, that's how he served people and he made blankets and scarves, was appointed "Judge of Peace" many times and he ended up being secretary of the administration of the community president. People in town would go to the punas (highlands) with their animals every August, that's why they could not assume any positions, because they had no time; we didn't have animals nor land in the highlands, we were always in the town...He didn't have any affiliation to the Shining Path, but he served people, that's why the Army took him... because they thought we were terrorists. ${ }^{21}$

The Peruvian Army Soldiers were not the only ones who used the term terrorist. On one occasion, a group of my respondents traveled to Lima to seek for information about their family members. One respondent, Carola, feels that they were considered outcasts in Peruvian society:

and when we went to Lima, everyone, in the bus, in the Palacio de Justicia, called us terrorists. We did not care, we only cared about our family members, about our loved ones, we just wanted to find them, so we did not listen...but now you ask me, and it really made us think: who are we? Why do they keep calling us terrorists? So much we suffered, sometimes they wouldn't let us in the buses, because they said: "oh, look at those Cholas ${ }^{22}$, the mothers of terrorists..." So we walked, we slept

20 INEI (reference)

21 Interview, July 10, 2011

22 A term used to refer to Andean women, commonly used in a demeaning way. 
in the plaza, in Lima, and then we came back (to Ayacucho) and we realized we had become the lowest people in our own land, we suffered, but we didn't care, we wanted our kids back, our husbands, we had a goal. ${ }^{23}$

Virginia talks about the difficulties of finding resources during those times. She is also conscious of how she was perceived by the rest of society:

I knew how it was... we suffered in different ways, people thought: Oh, she lost her husband, her children. But we also suffered in other ways...I washed clothes in a house but was fired because my patrona ${ }^{24}$ thought I was a terrorist...I understand during those times, people were killed everywhere, so people were afraid, I understand her (patrona), she was afraid...but I was fired, no one wanted to hire me, and I wanted to go back to the fields, but how could I? It was even worse there, so we just stayed, the terrorists with no arms or money...we did not even have a house! Maybe if we were terrorists we could have been protected, have food, but never, God would have punished us even harder.

Based on my interviewees' responses, I find that the conflict in Ayacucho created a new status of people. This new status of people was not exclusive of the rural or urban areas. My findings show that those who were left with little or no means of production, were dispossessed of their land, and were displaced were considered "terrorists" by the rest of society and faced greater obstacles than others in trying to carry on a normal life.

\section{iii. The Weakening of Community Ties in Rural Areas}

The chaos and confusion throughout Ayacucho led to the destruction of trust in others, weakening community ties. According to my respondents, women throughout the region even started to wonder why their family members were killed if they had no ties with the Shining Path or the Peruvian Army.

My respondents coming from rural areas talk about the destructive nature of gossip. Trying to make sense of the chaos, the words gossip and envy appear again and again throughout the testimonies coming from my rural interviewees. In the urban areas, gossip did not seem to play a role as important in interpersonal relationships. As one of my respondents says: "over there, in the fields, many people died because of envy and because of gossip. That didn't happen much here in Huamanga." ${ }^{25}$

Consuelo tries to make sense of the disappearance of her husband and is convinced that people in her community were involved in it:

I don't know why they (other community members) have made my husband disappear, maybe because they were envious or sought revenge because he was an authority.

Consuelo was not alone in her confusion. Another respondent also shared how difficult it was to trust the people in her community during the times of conflict:

$23 \quad$ Interview, July 9, 2011

$24 \quad$ Female boss

25 Interview, July 25,2011 
So many people have left their houses, their animals, their towns, they had to escape to the mountains, then when they came back, they thought everything was fine, but then again, the Army came, and started looking for terrorists and they got the dirigentes, the leaders of the people who organized to protect themselves, the young ones, the soldiers would say: you are terrorists, you did this, and they killed them...it was the envious ones, they sent the soldiers...you couldn't trust anyone back then. ${ }^{26}$

The violence and human rights violations that took place in the region and the weakening of community ties of trust allowed the Shining Path to become stronger in the rural areas. As Kimberly Theidon explains in her book Entre Prójimos, the abuses generated grievances and the desire for revenge between sectors of the population; it was precisely these hatreds and grievances that the Shining Path used as mechanism to break the trust among community dwellers (Theidon, 2004: 24).

\section{The Emergence of Women Leaders}

I think women became so involved first to protect their families and second, to belong to the struggle, because the struggle was for everyone in general, against all these things that were happening then. Yes, women leaders emerged to protect their families but also for the situation there was in Ayacucho. ${ }^{27}$

Part of the organizing tactics of the Shining Path was to include women in their agenda. The Shining Path confronted the female leaders who resisted joining them or refused their ideas. While the government focused on gaining support from public opinion and elites in Lima, the Shining Path focused on gaining support from small communities and groups in the Andes. An unfair dichotomous conception of the dynamics of the conflict outside of Lima prevailed back then: peasants and rural people would most likely support the Shining Path while middle-class and upper-class Peruvians would support the government and therefore any strategies they proposed to eradicate the Shining Path. This was not true.

Local leaders, who were mostly women leading organizations such as ANFASEP, because so many men had been killed and "disappeared," reduced the chances of the Shining Path to gain power in the communities. These leaders played the role of what Sartori refers to as "opinion makers" (Sartori, 1991). Opinion makers were not only in charge of the circulation of ideas through their social networks and organizations, but also became a sort of "filter" of the messages offered by the mass media channels. Mass media channels rarely addressed the situations outside the main cities. Consequently, the voices of local leaders or communities were unknown to the national public. This lack of communication also affected the local leaders, for they lacked real information of the national contexts and lacked support and strategies to organize effectively.

These women leaders were caught in the middle of two powerful enemies: the Shining Path and the Armed Forces. When asked whom would they support if they could go back in time, forty-two out of my forty-eight interviewees responded "neither", while six preferred not to answer. The women leaders gained the respect of the communities because of the support they gave to the affected population: their solidarity and the economic help their organizing provided to poor households, including their own. Because the violence affected 
their political organizing skills, these organizations stopped being a space where people could solely organize and became a space where basic survival skills were developed.

It was rare for Ayacuchanas to be involved in politics of any sort prior to the conflict. It was during the 1980s, the decade in which most men in Ayacucho were killed, that a new class of female organizers emerged. The emergence of female organizers and massive organizing in Ayacucho was a surprise to Peruvian politicians as well as to local leaders. Clubes de Madres ${ }^{28}$, Vaso de Leche and Comedores Populares ${ }^{29}$ started to emerge.

These women did not become leaders by choice, but rather by necessity. However, the way they refer to leadership is linked to the shift of gender roles: a woman is considered a leader when she starts taking traditional male roles. For example, in the absence of her husband, Eugenia had to take on the roles of a father and mother:

During the 1990's, I would come here (ANFASEP) sporadically, because I was still working on my trial and you know when you are on a trial, you must be attentive. After so many years, seven years, I finally got a pension for my kids, I had to get it, or else how could my kids eat if their father is gone? I had to be their father, mother and father. ${ }^{30}$

The assassination of the traditional heads of household, their husbands or older sons, led to the redefinition of gender roles in Ayacucho:

I have now assumed all of the responsibilities my husband and I shared. I am a mother and a father; I work on my farm, borrowing money from the bank to provide for my kids. ${ }^{31}$

When talking about leadership, my interviewees refer to situations in which they had to take on traditional male roles to organize their community. In their own words, "a leader, you know, a woman with pants under her pulliracha." ${ }^{32}$

When asked about female organizing during the 1980s, a respondent shares:

I think all women started to become leaders, for protection and for the people in general...If it had been a simple conflict, then the men could have stepped out and we women would have hid. No, it was all of us and specifically, women are more leaders than men, we are more leaders than the guys ... women are very capable, more than men, maybe the only difference is the genitals and maybe they are a bit stronger physically, but not in thinking or talking. ${ }^{33}$

The respondent later shared that she was proud of the role women fulfilled during the conflict because she thought: "what we did is what stopped them from killing all of us." In a nutshell, being forced to step out of the traditional gender roles that existed prior to the conflict empowered the women of Ayacucho.

\section{Changes in the Organization During the Conflict}

As the number of leaders and organizations multiplied throughout the region during the conflict, the state became more repressive. During the 1980s, ANFASEP members became aware of the

28 Organizations led my local mothers to provide protections for low-income mothers and their children.

29 Community kitchens were low-income residents have access to basic meals.

$30 \quad$ Interview, June 17, 2011

31 Interview, July 6, 2011

32 Pullera, traditional skirt women in the Andes wear. Pulliracha: diminutive of Pullera in Runasimi (Quechua)

33 Interview, June 18, 2011 
importance of protecting themselves and of the risk of losing more members. Negotiating legal matters with a repressive state and taking a political stand was not a possibility for them at that moment. It was in this context that the members of ANFASEP changed the focus of their organizational goals.

The economic impact that the conflict had on the families as well as the absence of paternal figures increased household poverty levels and the incidence of child labor. ${ }^{34}$ The members of ANFASEP focused on creating a "Comedor de Niños," or children's dining room, for their children to ensure that they were able to eat enough.

One respondent shares:

In 1984, I would go to the Comedor at ANFASEP with my children. That is where...I would get food and then I would go back to my town [...] it was what we needed at that moment. ${ }^{35}$

As the violence increased, the number of orphaned children started to rise. Mama Angelica traveled to Lima to ask for help from different institutions, such as churches, SERPAJ, and the Episcopal Commission of Social Actions (CEAS). ${ }^{36}$ During those times, Ayacuchanos were stigmatized by Peruvian society and labeled as terrorists, which made it hard for ANFASEP to raise funds for the Comedor.

With the help of a few donations, ANFASEP managed to run the Comedor for twelve years (1984-1996). It became a key component in the development of the organization: it was through that decade that ANFASEP's leaders learned how to connect with other organizations and put an emphasis on strengthening their relationship with the transnational pro human rights community.

\section{Social Capital as a Result of Organizing}

When talking about the past, my interviewees share that the types of violence were different in rural and urban areas. However, the violence in rural areas was more intense. Regardless of the past experiences, one single status of people emerged during the conflict. In a way, the conflict homogenized a segment of Peruvian society: indigenous people, peasants from Ayacucho, and relatives of the disappeared became known as terrorists. Furthermore, my data shows that by being forced to step out of their traditional gender roles, women leaders emerged during the conflict.

My forty-eight interviewees have experienced different types of violence but share common interests. They all now live in or in the vicinity of the city of Huamanga and they are all members of ANFASEP. The interviewees who were in Huamanga during the time of the conflict (16) had to either move to another barrio (11), or leave their rented houses because they were considered "terrorists" (4). Only one interviewee lives in the same house where her husband and her son were kidnapped and disappeared from. Seventeen (17) women referred to themselves as "poor" or mentioned, "not having enough resources to survive." Most women worked primarily in the market selling food (21), creating and selling their own crafts in the market or fairs (13), making chocolate and selling it on the streets (1), selling candy on the streets (7) washing clothes (4), and picking up bottles to sell to recycling companies (6). Four of them identified two jobs as their primary source of income.

34 The International Labor Organization (ILO) defines child labor as "work that deprives children of their childhood, their potential and their dignity, and that is harmful to physical and mental development." (ILO...).

$35 \quad$ Interview, June 30, 2011

36 Comisión Episcopal de Acción Social (CEAS) 
Twenty-six of my interviewees (54\%) showed a high level of involvement in the organization. They have been participating in regular activities for the past ten years, attending organized meetings, going on trips to Lima in order to protest, and attending workshops, and were often ready to help when their assistance in the organization was needed. Twenty-two of my interviewees showed an interest in participating but, though they attended mandatory meetings, they were either too busy or lived too far away to attend meetings regularly.

Moreover, my interviewees suggest that one of the hardest consequences of the conflict to deal with nowadays is the high level of poverty in the region. The Peruvian national poverty rate as of 2009 was at 34.8 percent while the poverty rate in Ayacucho reaches 62.7 percent. The province of Huamanga only, where I conducted my research, has a 53.6 percent of registered poor population. Put simply, over half of the population of Huamanga lives in poverty.

\section{i. NGOs in the region}

This high index of poverty attracted a large number of NGOs to the region. As of 2012, in the province of Ayacucho alone, there are 127 registered NGOs. There are 2,100 registered NGOs and civil associations in Peru. About 900 of them remain active and about 300 of them receive federal aid. And, between 2004 and 2005, NGOs in Peru received about 500 million dollars from international cooperation. ${ }^{37}$

Almost none of my interviewees, however, were involved in activities promoted by NGOs other than ANFASEP. Only one of them had participated in Finca Peru, an NGO that seeks to "generate integral solutions for the social inclusion and development of women and communities with low resources." 38 That interviewee shares:

The organizations have always helped us. Right now I am part of an association of artisans. I am also part of Finca Peru; I am a member. And here in ANFASEP I am a member, I am always here because here is where everything started, where I learned many skills and now I can be busy and active, it's hard at times... I continue..$^{39}$

As I developed my data, I questioned why only one of my forty-eight interviewees was drawn to programs facilitated by NGOs. The answer to this question would be an interesting topic to conduct research. A broad and basic answer I can offer, based on my interviews, is that women in Ayacucho prefer to be involved in organizations that they themselves started and control, instead of organizations that are usually funded by foreign NGOS and that "teach them" skills they can use in their every day lives, instead of learning together. I am not suggesting that the power relationships between organizations that are run by women are fundamentally different from the power relationships in foreign-funded NGOs, but in terms of preference, my interviewees prefer to be involved in self-run organizations.

Using the case of ANFASEP, one of the goals of this paper is to understand the role of civil society organizations and to understand the impact of an organization on the lives of its members. Although most of the members joined the organization for similar reasons, my data suggests that not everyone benefits in the same way from their affiliation with the organization.

37 (http://ipsnoticias.net/nota.asp?idnews=39366)

38 http://www.fincaperu.net/cms/index.php/finca_mision/es/

39 Interview, July 2, 2011 
To offer a better understanding of the dynamics within the organization, below is a chart I have developed based on my interviewees' responses and through an analysis of two of the organization's annual reports (2010-2011):

\begin{tabular}{|c|c|c|}
\hline & $\begin{array}{c}\text { TABLE } 1 \\
\text { ANFASEP ANNUAL REPORTS } \\
2010-2011\end{array}$ & \\
\hline Activity & Structure & Frequency \\
\hline Mandatory Meetings & Discussion of organizational goals, budgets, concerns. & Monthly \\
\hline Organizing Meetings & $\begin{array}{l}\text { No formal structure. Discussion of ideas. Members think of } \\
\text { ways to better their situation. Political discussions. }\end{array}$ & Every Tuesday \\
\hline Workshops & $\begin{array}{l}\text { Usually funded or initiated by other organizations. } \\
\text { Most of the workshops during } 2010 \text { and } 2011 \text { consisted of: de- } \\
\text { velopment of mathematic skills, Spanish lessons, domestic vio- } \\
\text { lence prevention seminars. }\end{array}$ & Twice a month \\
\hline Arts and Crafts & $\begin{array}{l}\text { Members get together to work on crafts to sell at the museum's } \\
\text { store. }\end{array}$ & Weekly \\
\hline Legal Advice & $\begin{array}{l}\text { Members can get legal advice regarding their cases and/or get } \\
\text { informed about new government policies. }\end{array}$ & Twice a month \\
\hline Community Cooking & $\begin{array}{l}\text { Members get together to cook; they bring their own ingredi- } \\
\text { ents and share with each other. }\end{array}$ & Every Sunday \\
\hline
\end{tabular}

Based on my interviews, I argue that the active members gain skills that are helpful for their everyday life, that their participation in activities in ANFASEP leads to participation in other community activities, and the more they participate, the more access they have to organizational networks that act as access routes to social capital.

\section{A. Skills}

One of my interviewees, who works forty-seven hours a week, shares how ANFASEP has helped her organize herself. She also explains how she thinks of the organization when she is not there. Although she works selling tamales in the market, my respondent makes time to be an active member of the organization:

When the ladies come here, they relax. Even when I don't come to one or two meetings I say: "I wonder what they are doing? What news have they heard? What are they talking about? Or even, who is arguing with whom? (laughs). What about the board, the members?" So I go there. I have to go there. Nowadays I sell food, tamales, I also come to ANFASEP reunions, and they help me organize myself. ${ }^{40}$ 
On the contrary, a respondent who is not an active member claims that she lacks the time to be involved in the organization. This respondent works forty-three hours a week. She goes as far as saying that she might be poor because of her low level of participation:

A: When you lost your husband, were you involved to other community activities?

B: No, where? Nowhere...I didn't have time, I had to educate my children, I had to prepare food, knit, I have educated my children with that... but I have never participated much...I think that's why I am so poor...but I never did... and I don't participate much now. ${ }^{41}$

At some point in each interview, most of the active and passive women members mentioned that they were aware of the skills ANFASEP offered through their workshops and organizing meetings. That, however, was not enough for them to become more active.

\section{B. Participation in Community Activities}

Another interesting pattern I found in my interviewees' responses was that the more involved they were in ANFASEP, the more likely they were to participate in other activities outside ANFASEP. Martha shares that she enjoys participating in community activities aside from ANFASEP and that she has learned key skills to improve her quality of life at ANFASEP, skills that she can now use in other spheres of her life:

A: Do you like to participate in community activities?

B: Sure, yes, I like to participate in stuff that benefits the community, help people with their needs.

A: Do you have any friends in your neighborhood?

B: Yes, I have friends; we have to do stuff together in the neighborhood.

A: Do you get along with all your neighbors?

B: Yes, I get along well with all my neighbors, only when we have to put money to put new doors they won't share money! For example now we have to get a topographic study, the engineers have to do it and it costs 100 soles. We got together and we have to raise that money, so we made a budget, so this afternoon I have to unite the people in my block, so we have to make an activity of any sort to make money.

A: How did you learn to make budgets and this kind of stuff?

B: I learned ... with life...in ANFASEP also...we have to do all kinds of stuff, be active, so you learn how to manage situations...it's good for us. ${ }^{42}$

Like many other of my active respondents, Martha shows a level of enthusiasm the less active members did not have. Martha acknowledges that "being active" in the organization is good for her. On the contrary, the less active members showed a lack of enthusiasm towards life in general. Constanza goes as far as saying that she has no friends in the organization. Still, she continues to attend mandatory meetings. Her statement is interesting, considering she

$41 \quad$ Interview, July 29, 2011

42 Interview, July 3, 2011 
was elected secretary during the annual elections and therefore must have some sort of support in the organization:

A: Do you have close friends in ANFASEP?

B: No one is really close to me in ANFASEP. That is why I am only occasionally there; because they named me secretary, I go but I get tired, because from here to there, to spend on bus fare, etc...we also don't have money so the ones who live close to ANFASEP they get involved more now. ${ }^{43}$

One of my interviewees clarifies why it is that Constanza was elected secretary during the annual elections:

A: And are you friends with the members of the executive board?

B: Yes and no, some executive board members I don't talk much to because they don't come often like me...the secretary for example, she says hi, we occasionally talk but not as much.

A: Did you vote for her?

B: Oh yeah, I did, because I think people deserve a chance to participate even if they don't come as often, and I know we all think that way, because we are together on a struggle... and who knows, maybe they (passive members) start coming more if they have to, do you understand? ${ }^{44}$

In the next section, I will explain how participation leads to positive outcomes and access to resources that are produced through organizational networks, also known as social capital.

\section{Networks and Social Capital}

As stated in my methods section, twenty-six of my interviewees showed a high level of involvement in the organization by participating in regular activities, attending and organizing meetings, going on trips to Lima in order to protest, and so on. These interviewees had a much better quality of life than those who did not participate on a regular basis. For them, ANFASEP became an access route to resources and to social networks that impacted their lives in a positive manner. One of my respondents shares how her life has significantly changed ever since she joined ANFASEP:

Our association always existed so I had to go to the meetings; I had to send documents, ever since my husband was killed in 1984; that has been my routine. Before, I was not part of the board so I would go to the mandatory meetings on the $30^{\text {th }}$ only, but I would also go to the ferias with other members and get animals...I like to know things, the cases of all the members. We always have reunions, protests in Lima. That's how we live. ${ }^{45}$

$43 \quad$ Interview, July 3, 2011

$44 \quad$ Interview, July 6, 2011

$45 \quad$ Interview, June 18, 2011 
On the other hand, twenty-two of my interviewees (46\%) showed an interest in participating in the organization's activities, but only attended mandatory meetings. Reina works forty hours a week and also states that she does not participate more due to lack of time:

I go to the meetings because I want to be a member, but I don't have time to go...or I don't know why I go... but I will always be a member...maybe in the future I will participate more, not now. ${ }^{46}$

Although the interviewees who were not as active kept mentioning that they did not "have the time," they did seem to be interested in participating more because they acknowledged the potential benefits they could get through the organization. They also considered ANFASEP a "part of their life," but did not take an active role in the networks embedded in the organization, and consequently were not able to access the resources offered through the organization.

In an effort to understand whether ANFASEP did not offer enough options for members to participate more often, I probed and asked questions regarding the women's involvement in other organizations. Sara shares that she "did not have time" to participate in other activities such as Community Kitchens or the Mother's Club:

A: When you came with your children, did you come to Comedores Populares, Club de Madres, etc.?

B: No, I didn't have the time...that's why I haven't gone...but at the Vaso de Leche, they only received elders... I went but I only received three cans of milk, I took fruits, oranges to sell, to distract myself but then they stopped giving milk and I don't go...I went to Club de Madres a couple of times, then to ANFASEP, I see how the members who participate more received hens, sheep, once. . .but for me? Nothing. Many have animals, rabbits; they receive and take it to the rural areas, but us? Nothing. ${ }^{47}$

Although Sara shows a certain level of discontentment, she does not take a proactive approach to receive the benefits the active members receive.

One of my interviewees' responses clearly shows how important the organization has become for her. When asked about the kind of work she currently performs, she asks me to clarify:

A: What kind of work do you do now?

B: You mean as a person or as part of an organization? ${ }^{48}$

Though short, her response shows that ANFASEP has become part of her identity. Furthermore, she gives a detailed explanation of her work life and the role of ANFASEP in the generation of her income:

B: Well, first thanks for coming to visit me to my humble home... I am investing time at home, going to the fields, and I am also cleaning. I am doing all that at home, and since we have a museum and some workshops at ANFASEP, I am doing some crafts at my home.

$46 \quad$ Interview, June 16, 2011

47 Interview, June 15, 2011. The interviewee mentions that the active members receive animals. I inquired about this and found out they only received animals a couple of times, as part of a donation. The members do not receive animals on a regular basis.

$48 \quad$ Interview, July 19, 2011 


\section{A: What kind of work?}

B: We are doing bags, right now we are doing belts, cards, so we can sell at the museum or to other organizations they connect us with, and that's all I am doing, as a member. So I am working on those things. ${ }^{49}$

Another respondent shares the positive impact ANFASEP has in her life. Her interests are not limited to accessing economic resources, but she is also interested in attaining justice, which was the organization's initial goal:

Now that I have become involved with ANFASEP more, we always have something to do, we have to coordinate what we are going to do with the organization, where can we go or where will we go denounce these cases we have...justice... reparations... so I always go there and ask to what can I do, with the president... and I do my own crafts to take to the museum store, when I have time I make them..$^{50}$

Based on my interviews, I conclude that women who participate more in organizations and who have stronger social networks have been better able to deal with the devastation caused by the violence that split their families and affected their communities between 1980 and 2000.

In sum, my findings show that positive outcomes for both the individual and community can emerge from group participation and social networks but these outcomes can only remain positive as long as the participation remains active, and the choice of participating more or less remains at the individual level.

\section{Sociological Significance and Conclusion}

My research offers an interesting analysis of the materialization of women's interests and how such interests became institutionalized. ANFASEP was originally created to address women's interests tied to the political violence experienced during the conflict. The chaos and new order of society, an order that did not respect these women's rights, reframed these women's interests. Using Molyneux's concept of practical and strategic gender interests, it is fair to claim that during the early 1980s, the women of ANFASEP's interests were strategic: they tried to navigate the system by organizing meetings with lawyers, asking the help of authorities, uniting with labor unions, and so on.

As time went by, these women's interests evolved: reframing their goals became a necessity, and ultimately, the need of survival and the changing social conditions of Peru became a priority. Practical gender interests emerged from the development of social capital. While organizing and becoming involved in social networks, women learned concrete skills to face the challenging situation of being second class citizens in a third world economy. In a nutshell, these women's forms of resistance evolved due to changing social conditions.

Thus, the internal conflict in Peru has brought with it a shift in the dynamics of the population in Ayacucho affecting both institutionalized and personal relationships. My findings show that organizations that provide assistance to affected populations, particularly to women, have allowed them to access resources that affect their quality of life in a positive manner as long as the members of an organization remain active and attend more than just mandatory meetings.

49 Interview, July 19, 2011

$50 \quad$ Interview, June 17, 2011 
In this way, organizations have become routes for active members to resources that are otherwise hard to access. The Peruvian state continues to fail to act as a protective apparatus, denying basic rights such as education and healthcare to poor populations, especially to the populations in the Andes. In the region of Ayacucho, the internal conflict intensified the pre-existent economic struggles, creating an environment in which survival was especially difficult for those who did not have the resources to migrate to safer areas.

My findings also show that the internal conflict affected the way people organize, the gender dynamics, and routes to resources. When organizations in Ayacucho started to emerge, both as a reaction to the repressive state and as a reaction to the Shining Path, they became independent terrains where new ways of organizing, survival mechanisms, and routes of access to resources emerged. I have also demonstrated that there were different types of violence during the conflict, and that the situation led to the emergence of women leaders in the region.

My research makes an important contribution to the literature on women's movements in Latin America, specifically in Peru, offering key insights about the evolution of women's movements into institutionalized organizations. Ultimately, I hope to use my findings and analysis to contribute to the development of an inclusive, persistent and solid process of Peruvian National Reconciliation.

\section{Bibliography}

Bebbington, Anthony, and Thomas Carroll. 2000. Induced Social Capital and Federations of the Rural Poor. Social Capital Initiative Working Paper 19. World Bank, Social Development Department, Washington, D.C.

Bracamonte, Jorge, Beatriz Duda, Gonzalo Portocarrero, eds. 2003. Para no olvidar: Testimonios sobre la violencia política en el Perú. Lima: Instituto de Estudios Peruanos.

Bourdieu, Pierre 2001. The Forms of Capital, in Granovetter, M. and R. Swedberg, (eds.), The Sociology of Economic Life. Oxford: Westview Press.

Coleman, James. 1988. Social Capital in the Creation of Human Capital. American Journal of Sociology 94 (Supplement): S95-S120.

Colleta, Nat J and Cullen, Michelle L., 2000. “The Nexus Between Violent Conflict, Social Capital and Social Cohesion: Case Studies from Cambodia and Rwanda. Social Capital Initiative." Working Paper 23. World Bank, Social Development Department, Washington, D.C.

Comisión de la Verdad y Reconciliación (CVR). 2003. Informe Final, Vols. I, IV, V, VI, VII, VIII, Apéndice I, Anexo 4, Lima: CVR.

Degregori, Carlos Iván, ed. 2003. Jamás tan cerca arremetió lo lejos: Memoria y violencia en el Perú. Lima: Instituto de Estudios Peruanos.

Del Pino, Ponciano. 1998. "Family, Culture, and Revolution: Everyday Life with Sendero Luminoso." In Steve J. Stern, ed. Shining and Other Paths, pp. 158-192. Durham: Duke University Press. 
Drinot, Paulo. 2009. "For whom the Eye Cries: Memory, Monumentality, and the Ontologies of Violence in Peru." Journal of Latin American Cultural Studies 18(1):15-32.

Enríquez, Laura J. 2000. “The Varying Impact of Structural Adjustment on Nicaragua’s Small Farmers." European Review of Latin American and Caribbean Studies 69 (October): 47-68.

Enríquez, Laura J. 2010. Reactions to the Market: Small Farmers in the Economic Reshaping of Nicaragua, Cuba, Russia, and China. University Park, PA: Pennsylvania State University Press.

González, Olga M. 2011 Unveiling Secrets of War in the Peruvian Andes. Chicago. University of Chicago Press.

Granovetter, Mark, 2005. The Impact of Social Structure on Economic Outcomes. Journal of Economic Perspectives. Volume 19, Number 1, (Winter 2005): 33-50

Grootaert, Christiaan. 1997. Social Capital: The Missing Link?.World Bank,

Expanding the Measure of Wealth: Indicators of Environmentally Sustainable Development. Washington, D.C.

Gugerty, Mary K and Kremer, Michael. “Social Capital Initiative Working Paper 20.” World Bank, Social Development Department, Washington, D.C.

Lehrer, Erica, Cynthia E. Milton, and Monica Eileen Patterson, eds. 2011. Curating Difficult Knowledge: Violent Pasts in Public Places. New York: Palgrave Macmillan.

Logan, William, and Keir Reeves, eds. 2009. Places of Pain and Shame: Dealing with "Difficult" Heritage. New York: Routledge.

Molyneux, Maxine. 2001. Women's Movements in International Perspective. New York, NY. Palgrave.

Orlove, Benjamin S. 1993. "Putting Race in Its Place: Order in Colonial and Postcolonial Peruvian Geography.” Social Research 60(2):301-336.

Portes, Alejandro. 1998. Social Capital: Its Origins and Applications in Modern Sociology. Annual Review of Modern Sociology, Vol. 24 (1998), pp. 1-24.

Ray, Raka, and A. C. Korteweg. 1999. "Women's Movements in the Third World: Identity, Mobilization, and Autonomy." Annual Review of Sociology 25:47-71.

Theidon, Kimberly. 2004. Entre Prójimos: El conflicto armado interno y la política de la reconciliación en el Perú. Lima: Instituto de Estudios Peruanos.

World Bank. 2000. World Development Report 2000/2001: Attacking Poverty. New York: Oxford University Press.

White, Geoffrey. 1997. "Museum/Memorial/Shrine: National Narrative in National Spaces." Theme issue, Museum Anthropology 21(3):8-27.

Williams, Paul. 2007. Memorial Museums: The Global Rush to Commemorate Atrocities. Oxford: Berg. 


\section{APPENDIX I: Open-Ended Interview Questionnaire}

a. Could you please tell me what kind of job do you have now? Probe: What do you exactly do? ( Production, clothing, arts, farming, construction, etc.)

b. When did you start working on your current job?

c. What about during the '90s, what kind of job did you have then? If none, what did you do?

d. What other responsibilities do you have besides your job? Probe: other roles, motherhood, social programs, grandmother, etc.

e. Are you involved in any community activities?

f. Do you play any other roles/ have any other responsibilities/ leadership in your community?

g. Could you describe a normal day for you? Probe: What activities are you regularly involved in?

h. What kind of community activities were you involved in during the 80 s and 90 s?

\section{Reflections:}

i. Do you think that things have changed, has your life changed since the conflict ended in terms of responsibilities and work?

j. Did you have to take on responsibilities that were difficult for you?

k. Statistics show that women-led homes here in Ayacucho are at a much lower risk of poverty than homes led by man. What do you think about this?

1. Is there anything you would like to share to help me understand the redefinition of women's roles here in Ayacucho? 


\section{APPENDIX II: Methods}

My data analysis is historically informed. I interpret the present dynamics at both the individual and collective level, but always going back to the process through which these dynamics emerged. Thus, the conflict and its relationship with the present is key when making sense of the collected data. In order to gain a deeper understanding of the effects of membership in the lives of the ANFASEP female members, I chose in-depth interviews as my primary methodology. In the interviews, I asked participants about their work, what kind of job they have now, what kind of job they had during the times of the conflict, what other responsibilities besides work they have currently, as well as their involvement in community activities, their level of involvement in ANFASEP and their participation in other organizations, if any. ${ }^{.1}$ In addition, I asked them about their perception of concepts such as leadership, solidarity, and justice and about Peruvian politics.

The forty-eight interviews were conducted at their homes. I chose to conduct the interviews at home to experience what their day to day was like, their living conditions, what they understood as poverty, what sort of life they lived, who they lived with and what the gender dynamics were at home. Interviews lasted an hour and a half to two hours. Overall, respondents were open to sharing and clearly expressed their opinions. After the interview, respondents usually invited me to eat at their homes or showed me their house, animals, and shared personal stories.

In conducting this study, I interviewed women between the ages of forty-six and sixtyeight who were members of ANFASEP, had been involved in the organization at least for ten years and who were economically active. The participants either had a job or worked on their own for at least thirty hours a week. Furthermore, the participants did not have a college degree or any sort of inheritance. This was a condition for inclusion in my sample. In addition, participants had lost a male relative who had either supported or contributed to the household economy in a significant manner. In this way, participants were not only emotionally, but also economically affected by the conflict. Participants did not hold any position of leadership prior to joining ANFASEP. Participants were, thus, made up of working women who were affected economically by the conflict on a similar scale, remained in Ayacucho and joined ANFASEP after the disappearance of one of their close male relatives. Some of my participants were fluent in Spanish, but most of them spoke Quechua. I worked with an interpreter who was with me during most of the interviewees.

Gathering an appropriate sample for this research was not a big challenge considering the amount of time I spent in Ayacucho. I first traveled to Ayacucho in January 2011 and spent one month participating in activities and getting to know the population. I structured my interviews in a way that could allow me to examine whether or not their economic situation during the 1980s and 1990s was fairly similar. Many of my interviewees offered a clarifying statement: If they had had enough resources to leave Ayacucho back then, they would have. Therefore, the participants were all women who did not have enough resources to leave for more secure areas.

I then traveled to Ayacucho for two and a half months to gather data during the summer of 2011. I recruited my respondents through direct contact and by making public announcements 
at ANFASEP. I made an announcement every Wednesday and Sunday for ten weeks, to make sure that participants who were not as active or did not attend every meeting were also included in my sample. Naturally, the first women who approached me after the announcements were the most active ones in the organization. Besides the public announcement method, I used a snowball sampling method and asked my first interviewees to refer me to women who were also part of the organization, but who were not as active as they, themselves, were.

The women interviewed (48) were displaced immigrants from rural areas (22); displaced immigrants from urban areas (10); Quechua-speaking only (29); had no relatives in Huamanga (21).

In addition to in-depth interviews, I also used participant observation as a secondary research method. The length of my stay in Ayacucho and the use of participant observation as a complementary method was a significant advantage for this project, for I was able to gain details and understand situations in a natural setting rather than an interview setting. I collaborated in community organizing throughout Ayacucho. This allowed me to understand the locals' civic and cultural practices, including the celebration of important Catholic holidays and Peruvian National Independence Day. I was also able to sit throughout meetings with the Junta Directiva ${ }^{52}$ at ANFASEP, where I observed the way this group of women organizes, what their priorities and challenges are as an organization and was able to identify the key leaders in the organization.

After participating in the previously mentioned activities, I would take notes and identify patterns of behavior that I considered significant. For this research, I also used quantitative demographic data gathered from the National Institute of Statistics and Informatics (INEI) to make comparisons of how poverty has decreased or increased in the region versus similar provinces throughout the Andes, the number of households led my male and women, basic data such as population, average income, education level, etc. I also used data from the Final Report of the Commission of Truth and Reconciliation. 


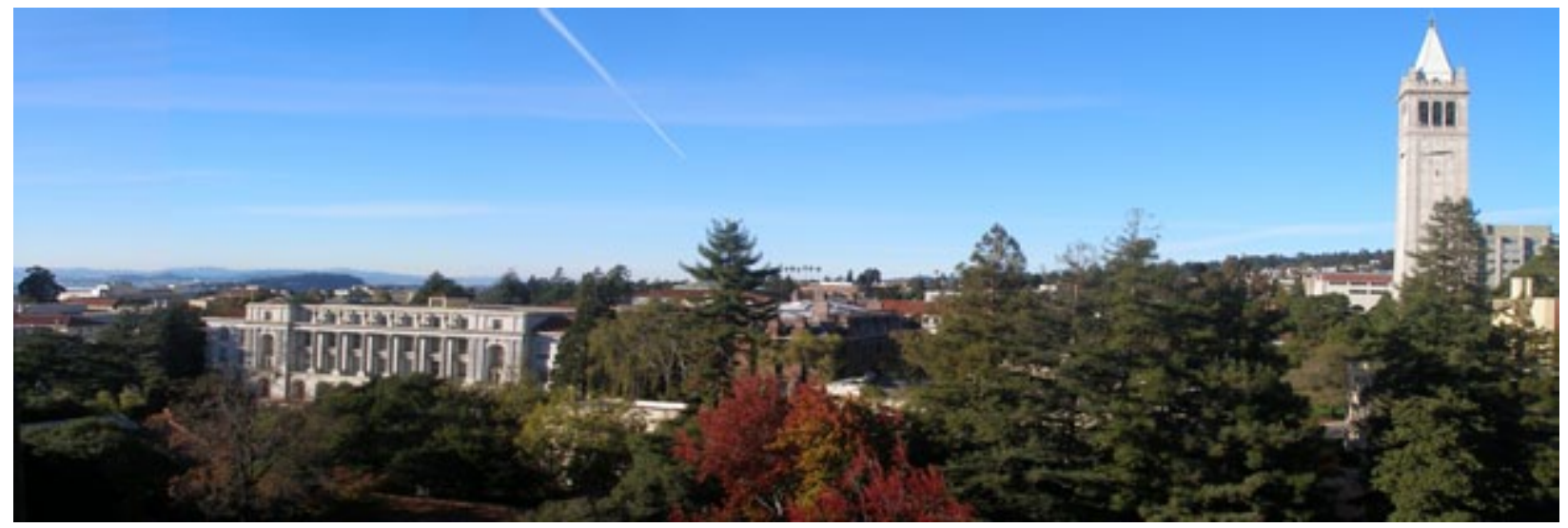

\section{Author Bios}

Vidya Balakrishnan is a member of UC Berkeley's Class of 2012 and graduating with double majors in Public Health and Psychology (Honors). Her research interests include: acquisition of Theory of Mind in young children and real-world applications of inferential statistics. Another primary academic interest lays in investigating the role of gene-environment interactions in causing social impairment in children with autism. Post university, Vidya aspires to apply to medical school in the hopes of one day becoming a developmental pediatrician to participate in the care of children with autism and other neuro-developmental disorders.

Luis Flores is a graduating senior at the University of California, Berkeley, where he is completing degrees in Political Economy and History. He is on the editorial board for the Berkeley Political Review and works at the Blum Center for Developing Economies.

Stephanie Lo graduated from UC Berkeley in 2012 with a BA in English (High Honors) and Media Studies. While at Cal, she was a Summer Undergraduate Research Fellow in the summer of 2011. She had the great pleasure of writing her English honors thesis under the supervision of Professors D.A. Miller and Catherine Gallagher from UC Berkeley's English department.

Justine Parkin graduated Magna Cum Laude in May 2012 with a degree in Interdisciplinary Studies where she combined her interests in political and social theory, geography, and theories of language. She was selected for a research grant to complete her senior thesis on Gandhi's philosophy of nonviolence through the Summer Undergraduate Research Fellowship program. She presented her findings at a research conference at the end of the summer. She spent her final semester studying abroad in Berlin where she continued studying many of the theorists who interested her throughout her undergraduate years and finally picked up a new language.

Sandra Portocarrero graduated with High Honors in Sociology. As a Haas Scholar, she worked with Professor Laura Enriquez as her advisor on a research project that looks at the effects of organizational participation in the well-being of Andean women in Ayacucho, Peru. Sandra is also an Institute of International Studies Junior Scholar and participated in the McNair Scholars program where she worked with Professor Kim Voss as her mentor. 


\section{Editor Bios}

Christiana Dunlap (Editor) is pursuing a bachelor's of arts in Political science with an emphasis in international relations and expects to graduate in spring 2013. In her spare time she enjoys playing the drums and keyboards in a band.

Ashley Gonik (Editor) is a first-year student planning to major in History and minor in History of Art and Jewish studies. In addition to her involvement with the BUJ, she also competes in Quiz Bowl and Model United Nations. She frequently visits the Pacific Film Archive Theater to indulge in her love of foreign cinema.

A fourth year at UC Berkeley, Britney Karim (Editor) is pre-law with an English major and an African American studies minor. Her hobbies include reading, freelance writing, and competing in the equestrian show circuit with her horse.

Tina Karimi (Editor) is a Media studies major and Public Policy minor expecting to graduate in spring 2013. Her favorite hobby is reading anything she can get her hands on-from literary fiction to nineteenth-century Gothic romances and everything in between. She is also a blogger at Smashion Babble, an online fashion and lifestyle marketplace.

Sara (So Yeon) Kim (Editor) is currently in her final year of study, pursuing a B.A. in Rhetoric. She enjoys the life of a student, reading at the various cafes in Berkeley and playing intramural volleyball with her friends.

Tammy Lian (Editor) is a junior at UC Berkeley pursuing a double major in English and Music. When she isn't reading, writing, or immersed in music, Tammy can be found at her desk making cards and discovering new crafty pastimes.

Emma Lundberg (Editor in Chief) is a senior at UC Berkeley, majoring in English with a minor in Music. When she isn't reading or writing, Emma enjoys learning foreign languages, cooking with friends, and playing violin in University Symphony Orchestra.

Natalie Oveyssi (Assistant Editor) is a sophomore Sociology major and Conservation and Resource studies minor. In her spare time, she enjoys reading everything from Jane Austen to J.K. Rowling.

Aditya Ramachandran (Editor) is a second-year Political science and intended Economics double major. While he isn't busy with schoolwork and editing, he can often be found trying to learn how to play the piano and in the student section during sports games, usually cheering along with the Cal Rally Committee.

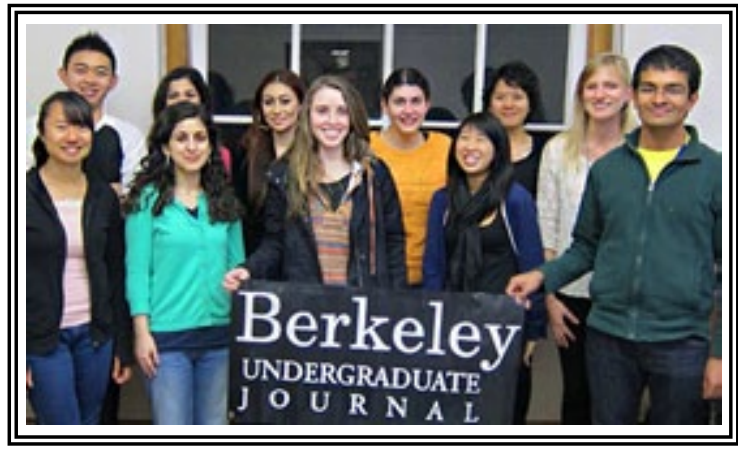

Berkeley Undergraduate Journal, fall 2012 editorial board.
Minerva Ramirez (Design Editor) is a third-year English major and Theater, Dance and Performance studies minor with a focus on Technical Theater. She enjoys watching anime, drawing in Photoshop, and walking around North Berkeley.

Mason Tran (Editor, Design) is currently a sophomore at UC Berkeley intending to double major in Biology and Media studies. In his spare time he enjoys playing sports, particularly volleyball and basketball. He also enjoys playing his flute. 